\title{
玉川毒 水除害の化學的研究
}

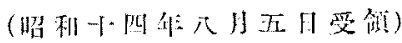

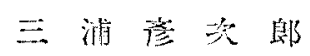

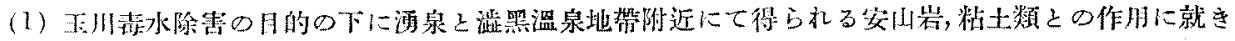

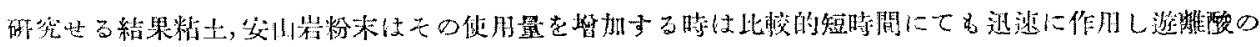

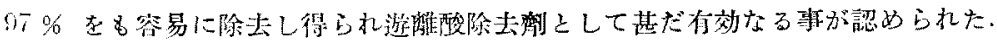

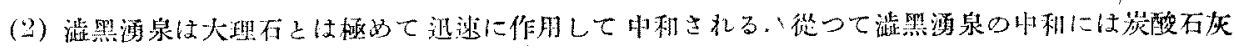
在健用し得ら゙れる。

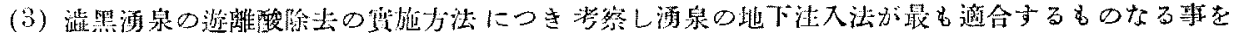
连心゙た.

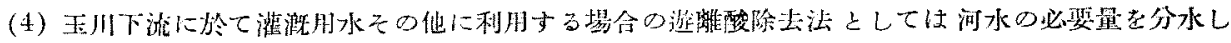

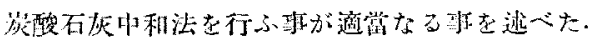

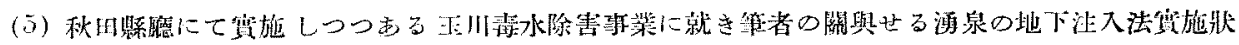

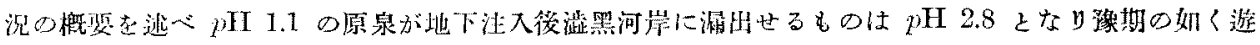

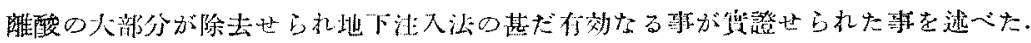

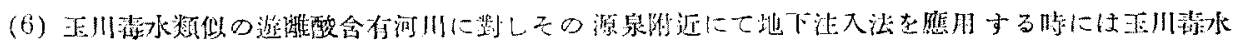

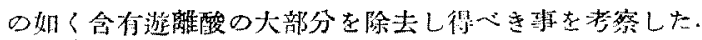

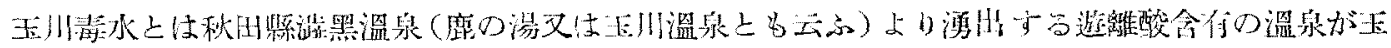

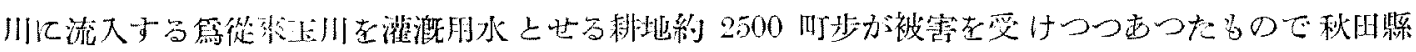

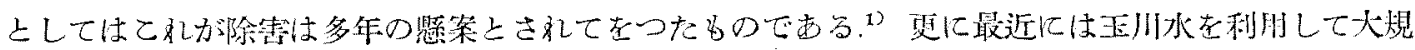

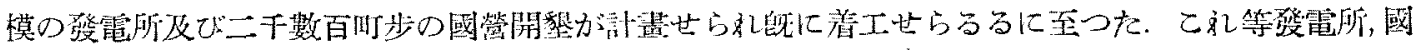

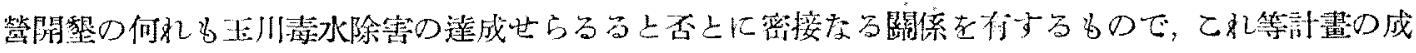

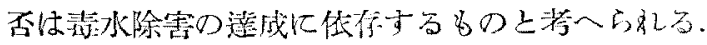

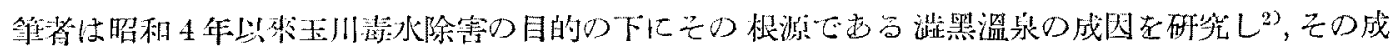

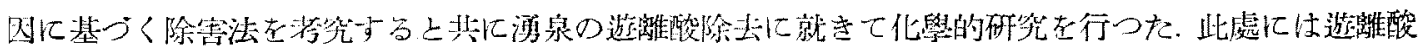

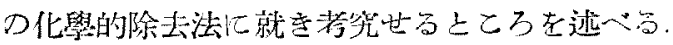

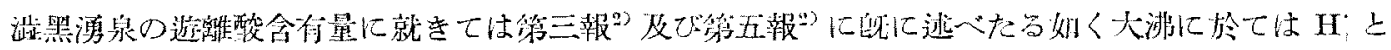

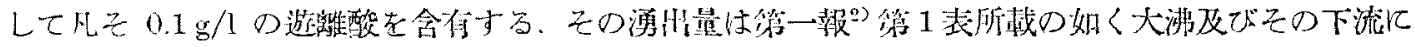

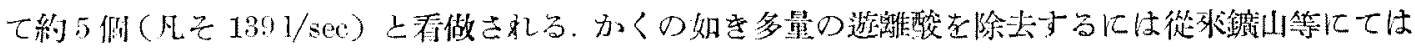

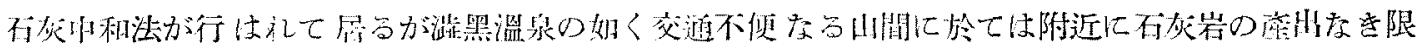

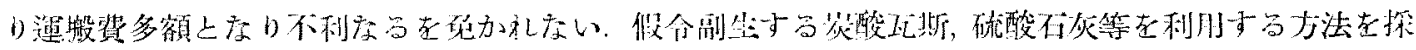

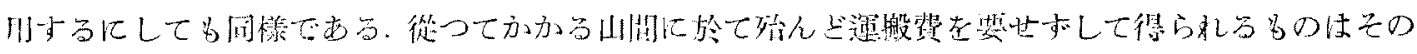

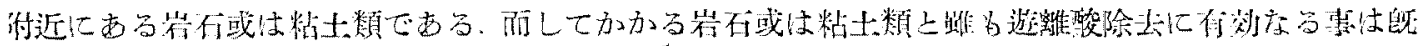

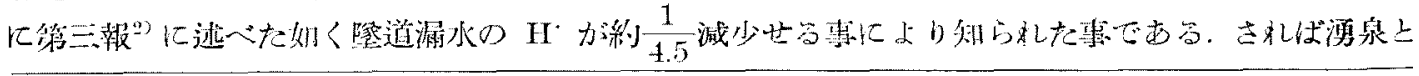

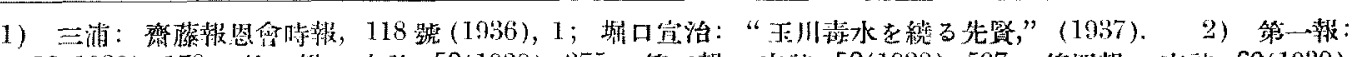

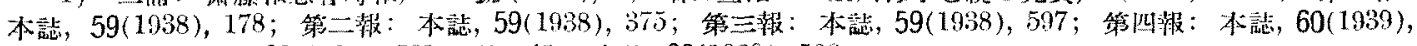

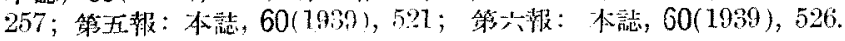




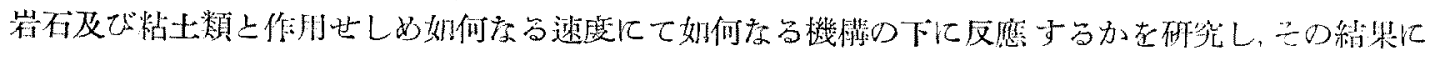

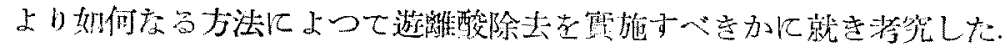

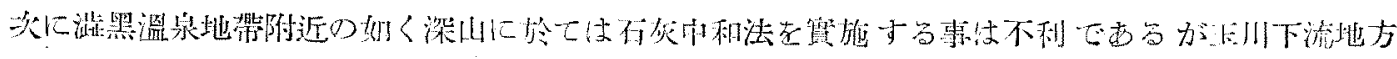

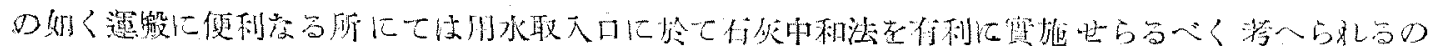

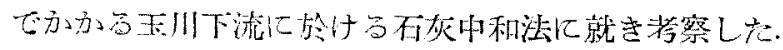

\section{I. 岩石, 粘土類による遊離酸除去法}

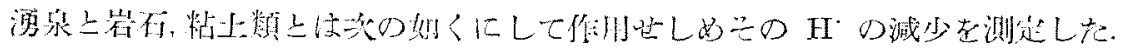

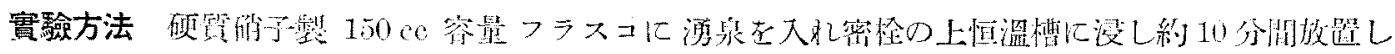

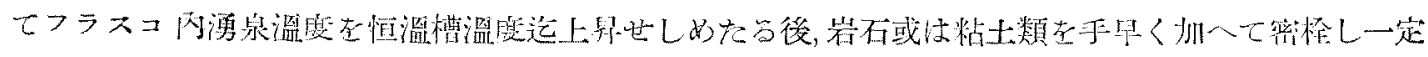

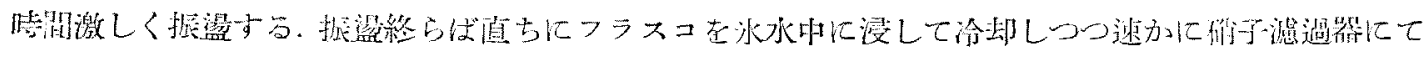

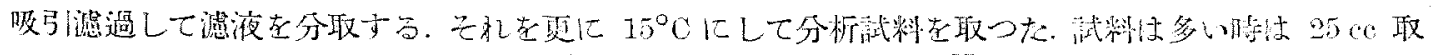

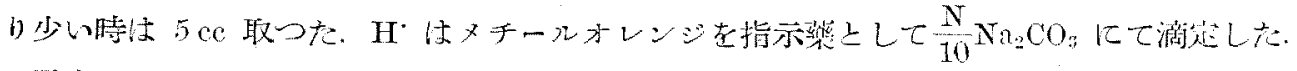

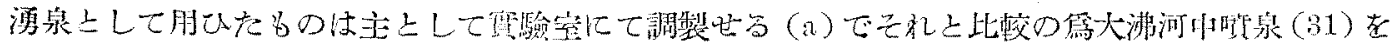

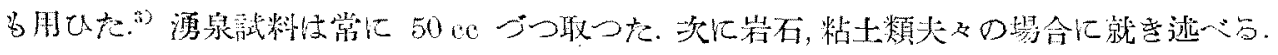

\section{1. 粘土を用ひた場合}

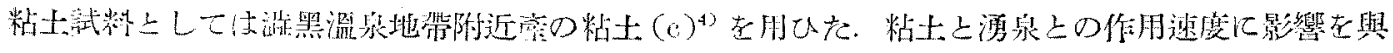

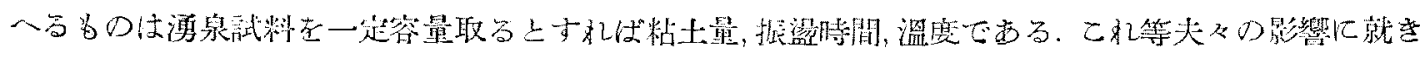

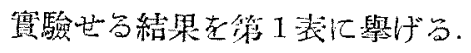

符 1 表

\begin{tabular}{|c|c|c|c|c|c|c|c|}
\hline 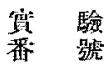 & ${ }^{\text {酒 }}(\mathrm{cc})^{\text {泉 }}$ & 糊士 $\underset{(\mathrm{g})}{(\mathrm{c})}$ & 溫 $\left.{ }^{\circ} \mathrm{C}\right)^{\text {鹿 }}$ & $\begin{array}{c}\text { 振齫時間 } \\
(\min )\end{array}$ & $\Pi \cdot$ 殘 $_{(g \text { in } 1)^{\text {量 }}}$ & $H$ & 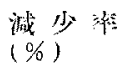 \\
\hline 8 & (a) & 10 & $70 \pm 0.2$ & 3 & 0.0075 & & 89.1 \\
\hline 10 & $"$ & 5 & $"$ & " & 0.0210 & & 69.3 \\
\hline 11 & " & 15 & " & $"$ & 0.0050 & & 92.7 \\
\hline 12 & " & 20 & " & " & 0.0032 & & 95.3 \\
\hline 27 & " & 30 & " & " & $0.00 \geq 0$ & & 07.1 \\
\hline 33 & " & 1 & $" \prime$ & 20 & 0.0354 & & 48.3 \\
\hline 31 & " & 5 & $"$ & 20 & 0.0070 & & 89.8 \\
\hline 14 & $"$ & 10 & $"$ & 1 & 0.0183 & & 73.3 \\
\hline 24 & " & 10 & " & 10 & 0.0050 & & 92.7 \\
\hline 20 & " & 20 & $"$ & 1 & 0.0069 & & 89.9 \\
\hline 26 & " & 20 & $" \prime$ & 10 & 0.0024 & & 96.5 \\
\hline 20 & " & 20 & $30 \pm 0.2$ & 3 & 0.0042 & & 93.9 \\
\hline 21 & $"$ & 20 & $50 \pm 0.2$ & 3 & 0.00088 & & 94.5 \\
\hline 41 & " & 20 & $10 \pm 0.2$ & 3 & 0.0075 & & 89.1 \\
\hline 16 & $\left(\begin{array}{ll}(31) & 50\end{array}\right.$ & 10 & $70 \pm 0.2$ & 3 & 0.0083 & & 913 \\
\hline
\end{tabular}

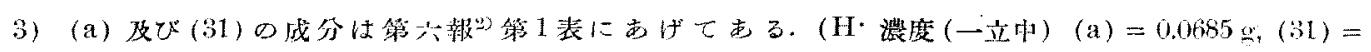

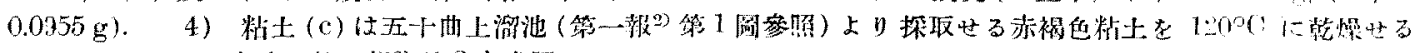

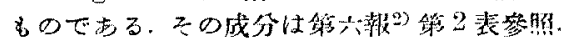




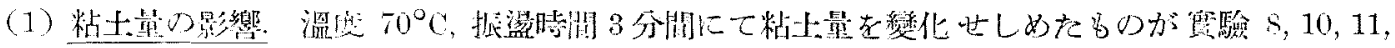

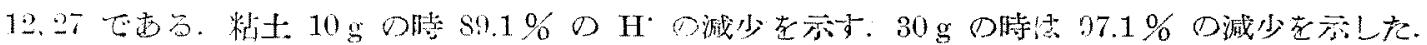

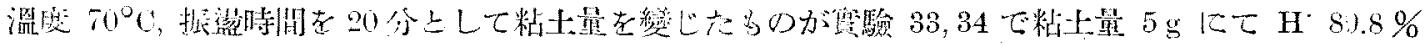

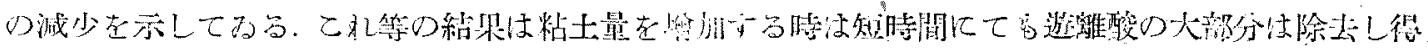

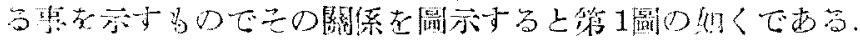

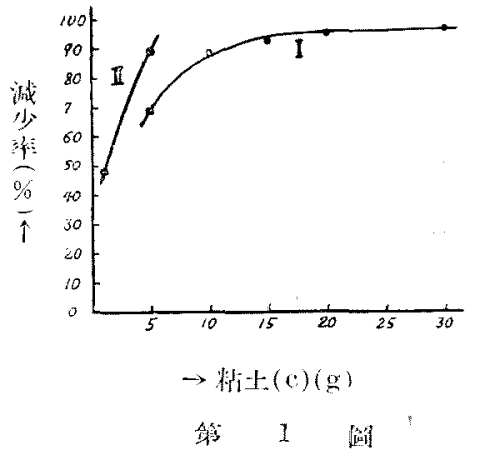

(a) 溶液 $50 \mathrm{cc}$, 淄度 $70 \pm 0.290$

I 振盜时間 $3 \mathrm{~min}$

II 振湆時閒 $20 \mathrm{~min}$

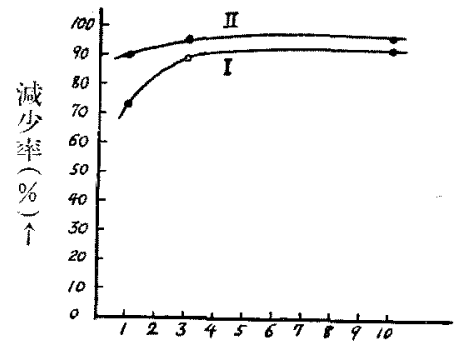

$\rightarrow$ 振温晴閒(min)

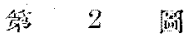

(a) 搈液 $50 \mathrm{co}$, 溫磨 $70 \pm 0.20 \mathrm{C}$

I 粘上 (c) $10 \mathrm{~g}$.

II 粘士 (c) $20 \mathrm{~g}$,

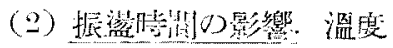
$70^{\circ} \mathrm{C}$ ，粘上量 $10 \mathrm{~g}$ 上して据 溜㭙闻在變化さしめたるのは 实驗 $8,14,-4$ で, 温鼠 $70^{\circ} \mathrm{C}$, 粘上量 $20 \mathrm{~g}$ として振㹂時間

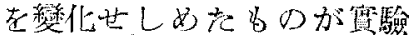
12,25,26でする.何和の場合 b最初の短時润印に大部分作 仃してこの後棈めて徐々に

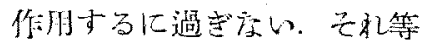
の閐係在第2圖化圖示士。.

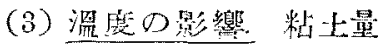

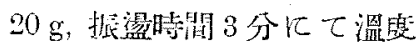

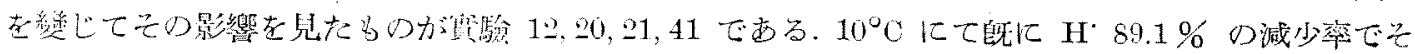

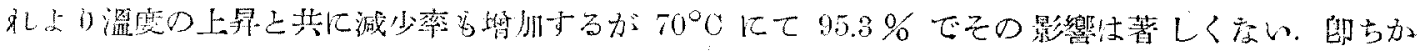

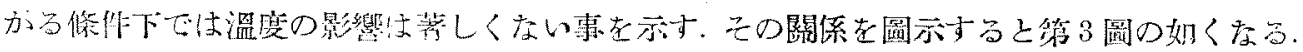

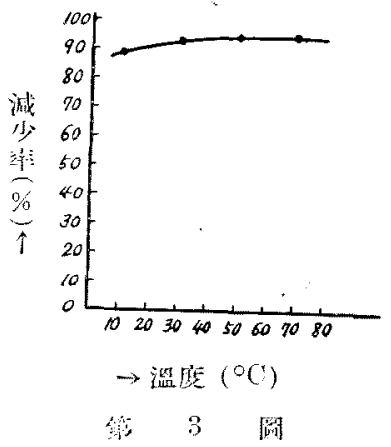

(a) 溶液 $50 \mathrm{cc}$, 将点 (c) $20 \mathrm{~g}$,

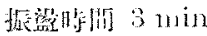

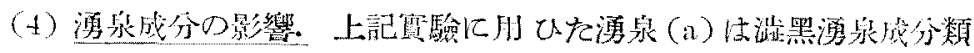

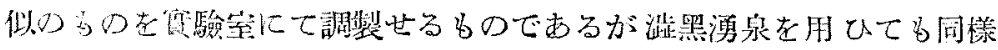

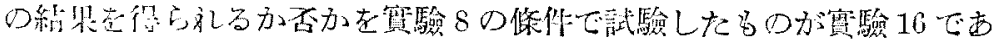

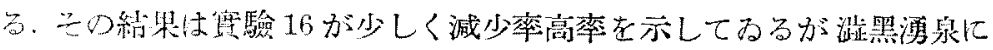

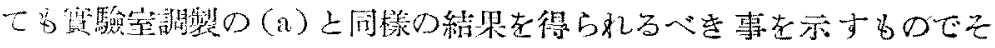

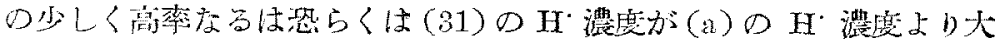

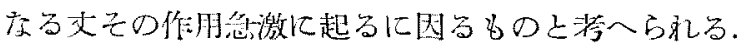

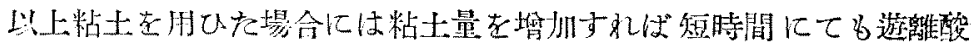

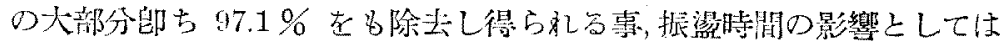

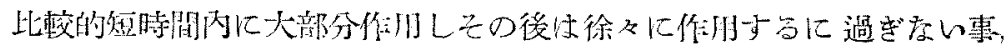

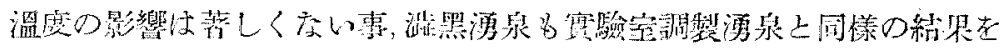

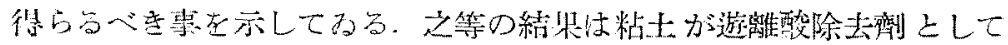

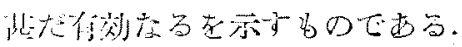

\section{2. 安山岩を用ひた場合}

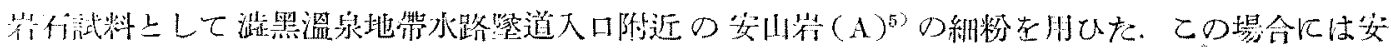

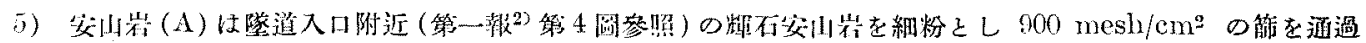

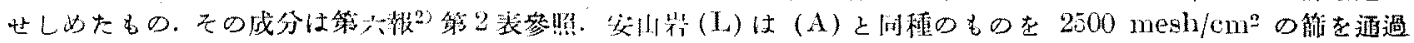
好めたるの. 


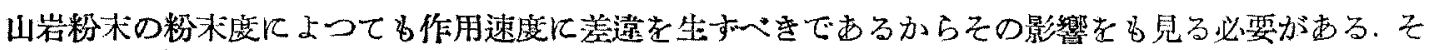
れ等に就き賽驗せる絬果を第 2 表に舉げる。

\begin{tabular}{|c|c|c|c|c|c|c|c|}
\hline 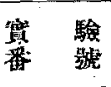 & 涌 & 安 & & 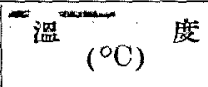 & $\begin{array}{c}\text { 振菹盟時間 } \\
(\min )\end{array}$ & $\begin{array}{l}H \cdot \text { 證 } \\
(g \text { in } 1)^{\text {量 }}\end{array}$ & 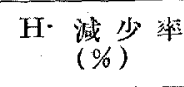 \\
\hline 13 & (a) 50 & (A) & 10 & $70 \pm 0.2$ & 10 & 0.0192 & 72.0 \\
\hline 19 & $"$ & (A) & 20 & $"$ & 10 & 0.0073 & 89.3 \\
\hline 28 & $"$ & (A) & 30 & " & 10 & 0.0020 & 97.1 \\
\hline 9 & $"$ & (A) & 10 & $"$ & 3 & 0.0350 & 48.9 \\
\hline 15 & $"$ & (A) & 10 & $"$ & 20 & 0.0135 & 80.3 \\
\hline 29 & $"$ & (A) & 20 & $"$ & 3 & 0.0151 & 78.0 \\
\hline 31 & $"$ & (A) & 20 & $"$ & 20 & 0.0040 & 94.2 \\
\hline 30 & " & (A) & 20 & $30 \pm 0.2$ & 10 & 0.0212 & 69.1 \\
\hline 32 & " & (A) & 20 & $47 \pm 0.2$ & 10 & 0.0136 & 80.2 \\
\hline 44 & $"$ & $\left(\mathrm{~L}_{\mu}\right)$ & 10 & $\quad 70 \pm 0.2$ & 3 & 0.0257 & 62.5 \\
\hline 17 & $(31) \quad 50$ & (A) & 20 & $"$ & 10 & 0.0083 & 91.3 \\
\hline
\end{tabular}

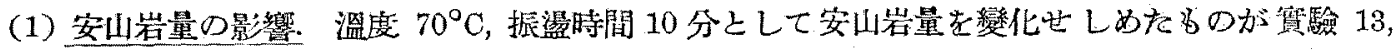
19,28 である. 安山岩 $30 \mathrm{~g}$ 用ひたるのは H $97.1 \%$ の減少率在示す. 即ち安山岩にてるその使用量

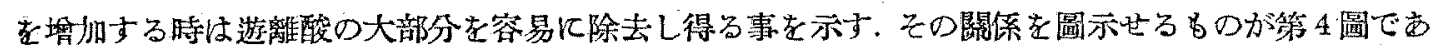
3 .

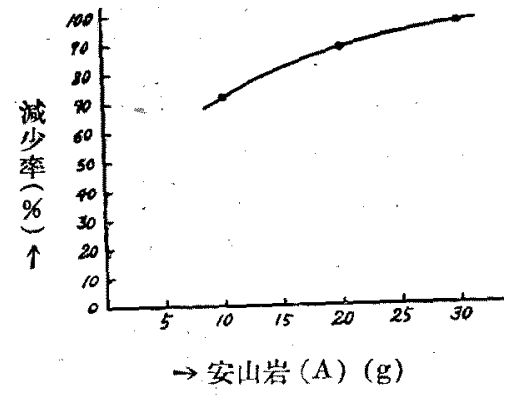

第 4 图

(a) 溶液 $50 \mathrm{cc}$, 㴧度 $70 \pm 0.2 \circ \mathrm{C}$ 振盪時間, $10 \mathrm{~min}$

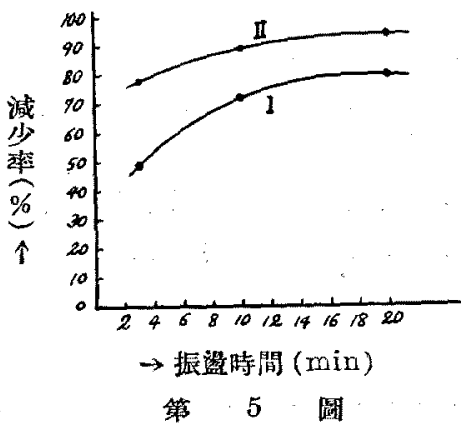

(a) 溶液 $50 \mathrm{cc}$, 溫度 $70 \pm 0.2^{\circ} \mathrm{C}$

I 筑山岩 (A) $10 \mathrm{~g}$

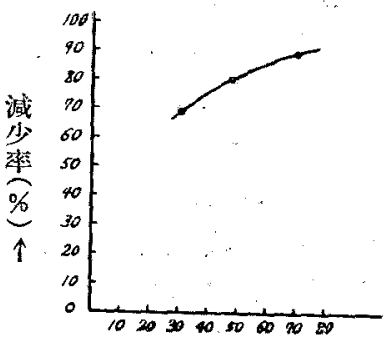

$\rightarrow$ 湓度 $\left({ }^{\circ} \mathrm{C}\right)$

第 6 回

(a) 溶液 $50 \mathrm{cc}$, 茹山岩 (A) $20 \mathrm{~g}$, 振澄時間 $10 \mathrm{~min}$

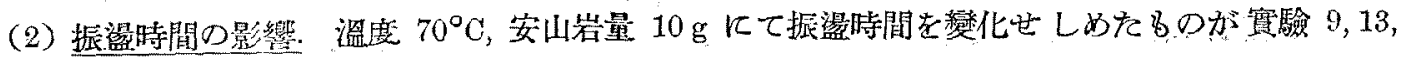

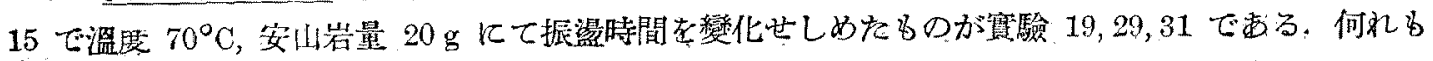

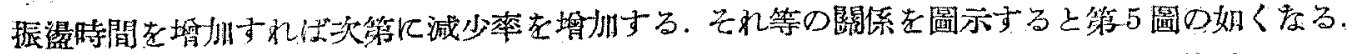

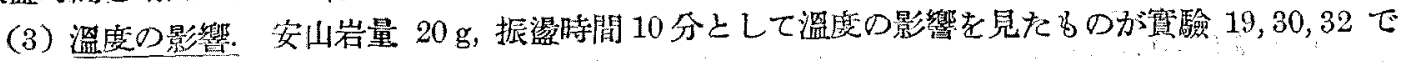

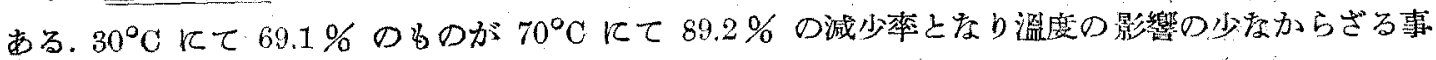
を示してわる. その關係を圖示すると第 6 圆の如くになる.

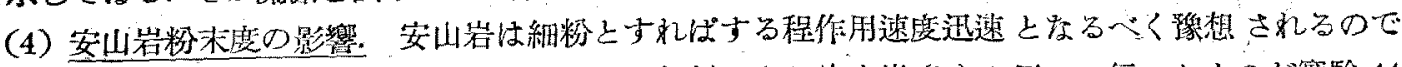

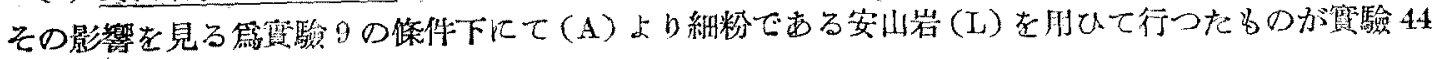




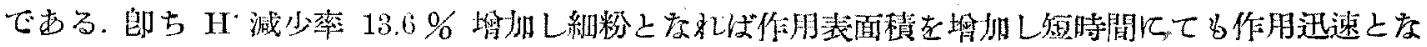
名事学示士。

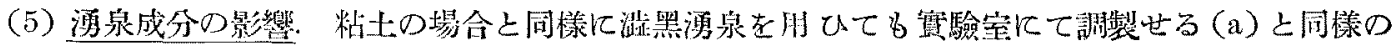

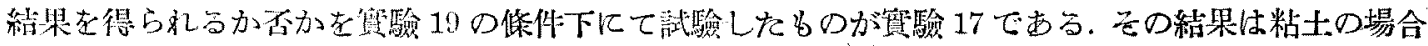

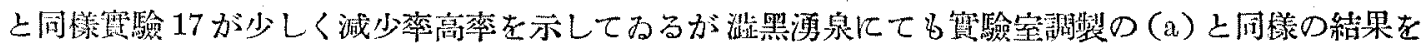

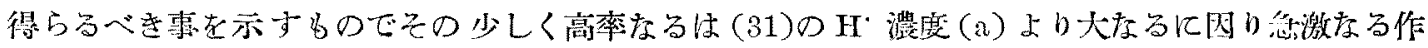
肘起方䉆上㹲入られら。

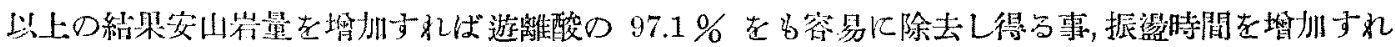

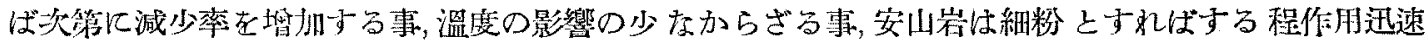

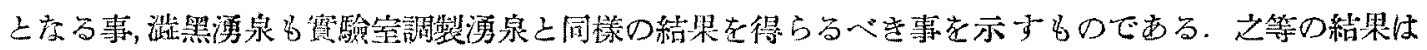

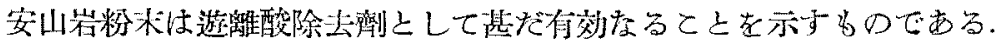

\section{3. 粘土と安山岩との比較}

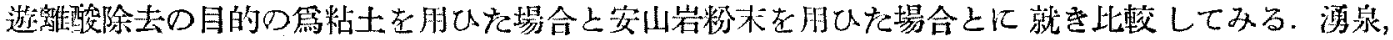

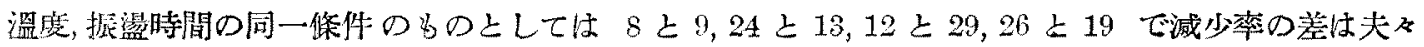

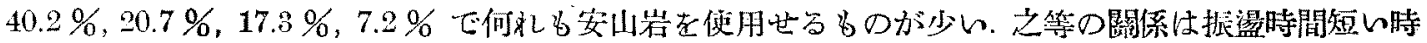

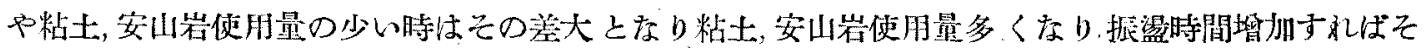

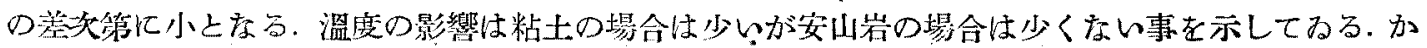
くの如を遊踓酸の減少は溶液中の H゙が粘土或は安山岩粒子に作用する第であるからてれ等粒子の

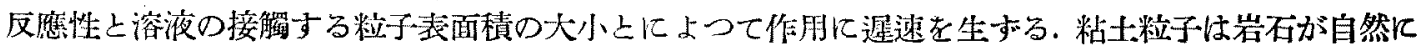

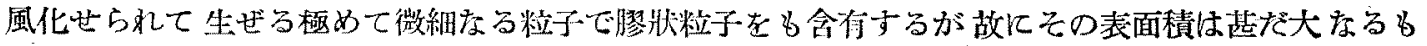

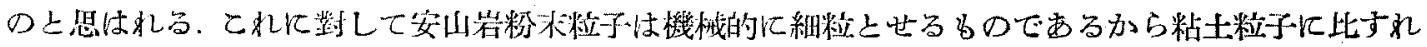

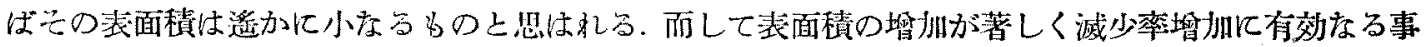

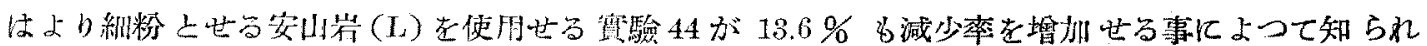

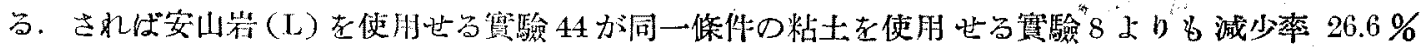

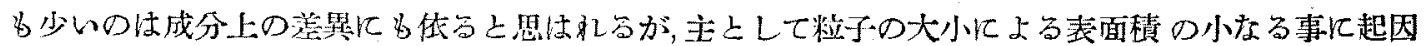

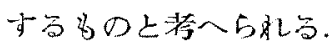

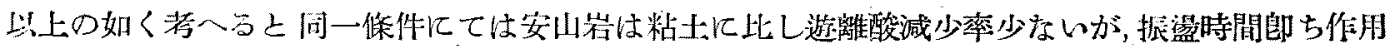

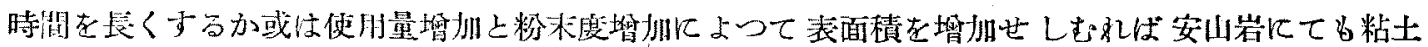

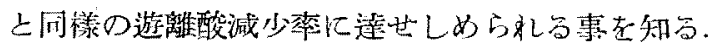

\section{4. 腐植土。砂, 白土, 褐色士, 灰黑色土, 大理石 ${ }^{6>}$ を用Uた場合}

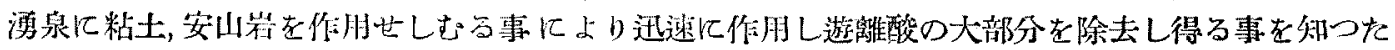

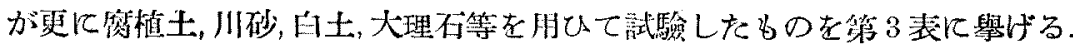

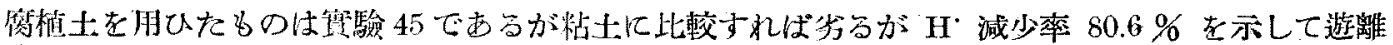

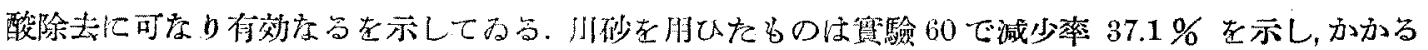

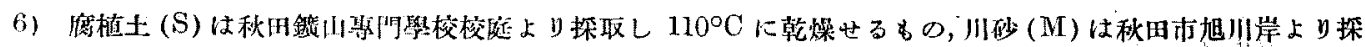

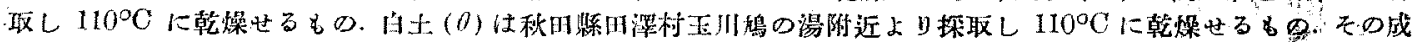

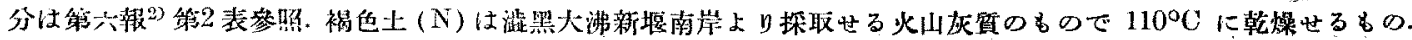

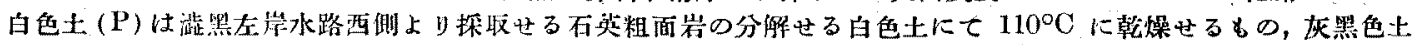

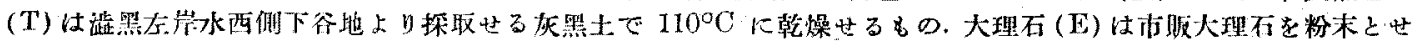
30 . 


\begin{tabular}{|c|c|c|c|c|c|c|}
\hline 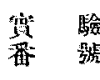 & 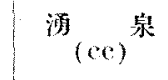 & 上, 砂, 不 & $\left({ }^{\circ} \mathrm{C}\right)^{\text {惩 }}$ & 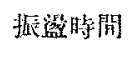 & 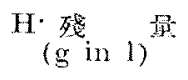 & $\begin{array}{c}H \cdot \text { 娍少然 } \\
(\%)\end{array}$ \\
\hline 45 & (a) 60 & 腾植走 (s) & $70 \pm 0.2$ & $5 \mathrm{~min}$ & 0.0183 & 80.6 \\
\hline 60 & $=n$ & 川告( M) & " & $70 \mathrm{~min}$ & 0.0419 & 37.1 \\
\hline $7: 3$ & " & 当斗 $(0)$ & ." & $10 \mathrm{~min}$ & 0.0528 & 22.9 \\
\hline 70 & " & 褐色上 $(\mathrm{N}) 20$ & ' & $3 \mathrm{~min}$ & 0.057 & 15.8 \\
\hline 76 & $"$ & 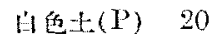 & " & 3 min & $0.050 t$ & 26.4 \\
\hline$\pi$ & " & 炏照色上( $\mathrm{T}) \leq 0$ & $n$ & $3 \min$ & 0.0268 & 160.9 \\
\hline 46 & $"$ & 人址石( $\mathrm{E})$ & $\prime \prime$ & $3 \mathrm{~min}$ & アルカリ悱 & 100 \\
\hline 43 & $" \prime$ & 人距石 $(\mathrm{E})$ & " & 15 sec. & 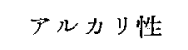 & 100 \\
\hline
\end{tabular}

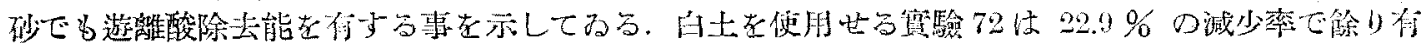

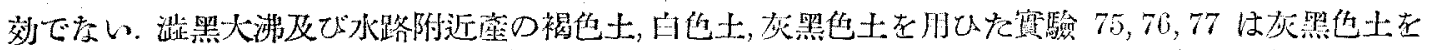

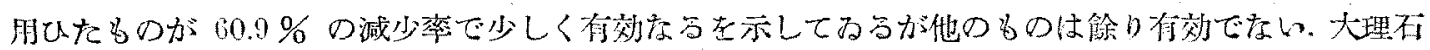

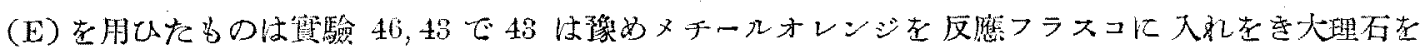

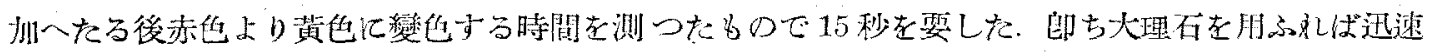
儿遊離酸在中和七得万事存示声。

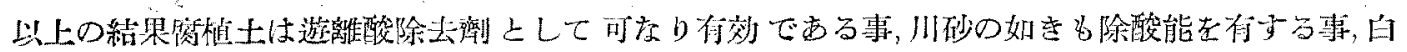

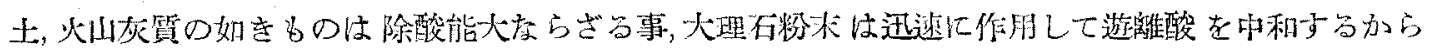

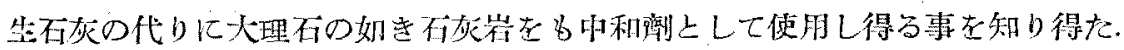

\section{5. 潰泉と岩石, 粘土類との作用機構}

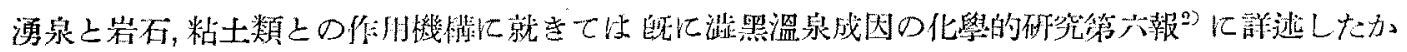
らここには少胳与る。

\section{6. 遊離酸除去實施方法}

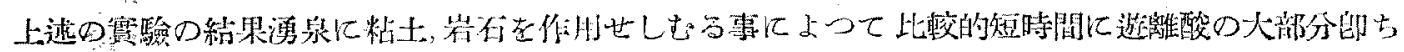

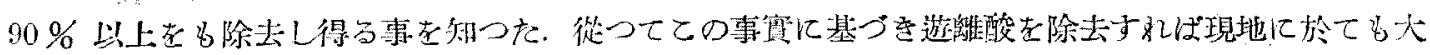

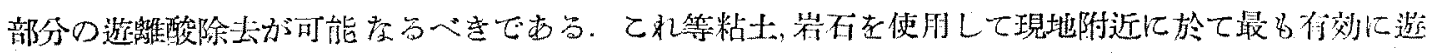

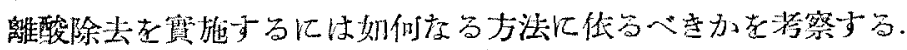

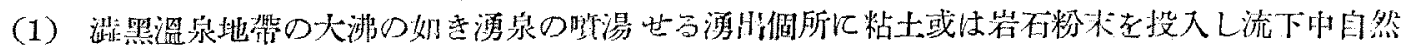
作朋世しむ方方法。

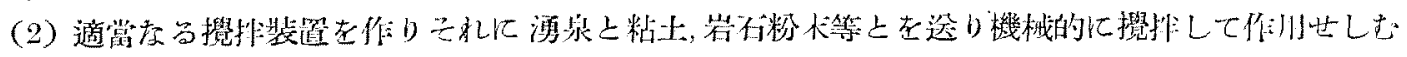
方方法.

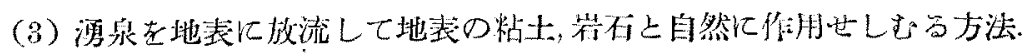

（4）洦泉地下に注入し地中にて岩不粘土類上自然に作朋せしむる方法

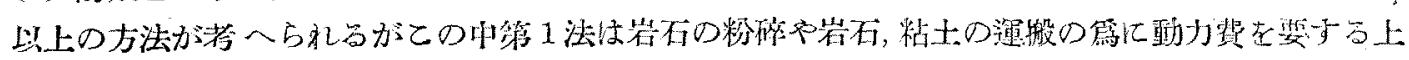

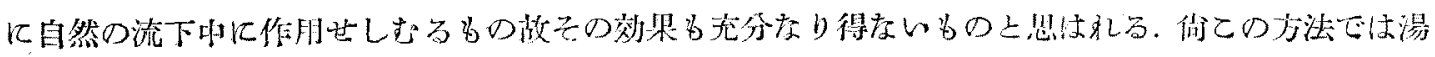

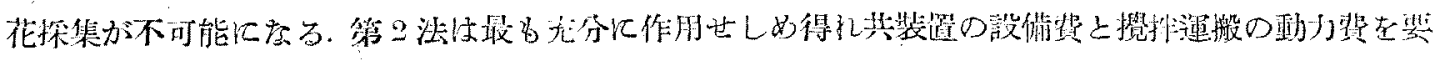

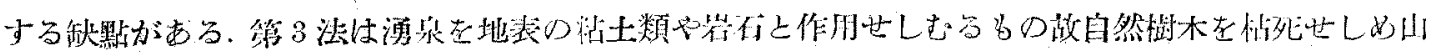

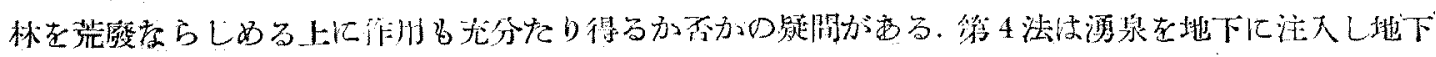

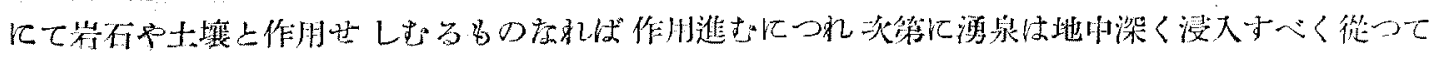




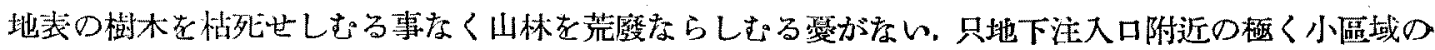
み影響を受けるに 過ざない，佾粘土，岩石を连搬する必要なく地中にては岩石や土壤の間老通過する

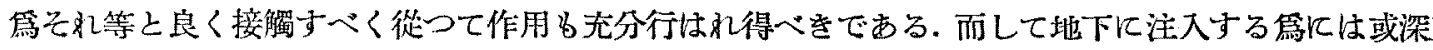
度迄ボーリングして注大与る方が適當と思はれるが滥黑涌泉地帶の水路附近にて涌泉の放流試驗を

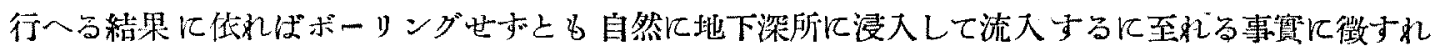

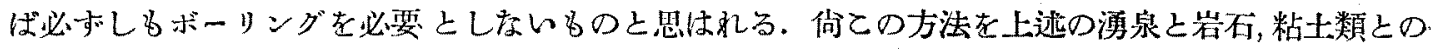
作用の賽驗結果上對批するに上述の賽驗では岩石細粉を使用したるのであるが地下てする岩石は大 塊として存すべけれ代かかる大塊では表面積小なる第作用緩慢なる上更に次第化表面皘を減じ作用

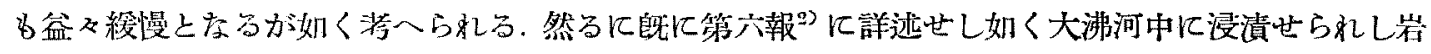

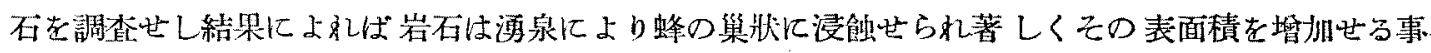

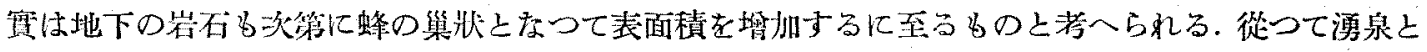

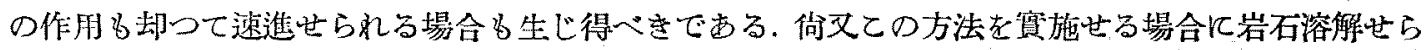

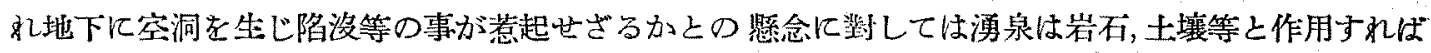

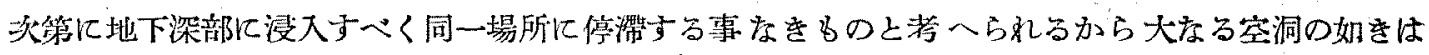

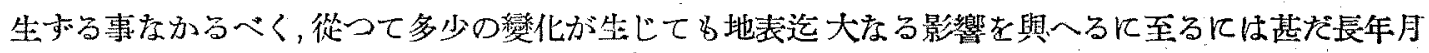

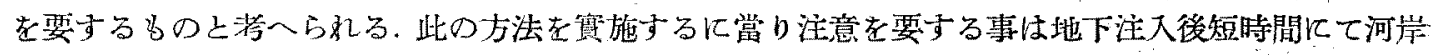

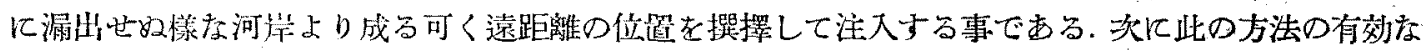

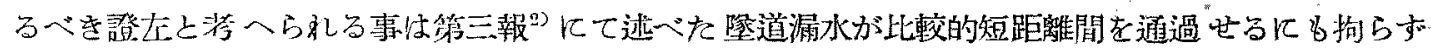

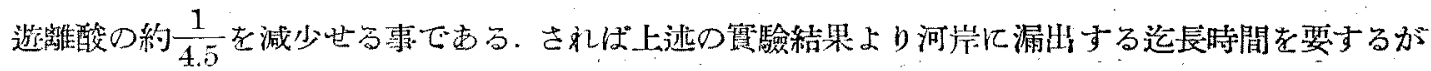

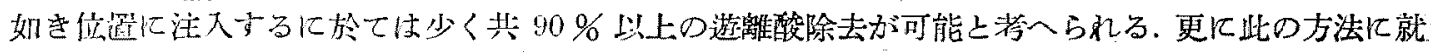

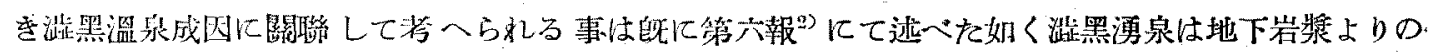

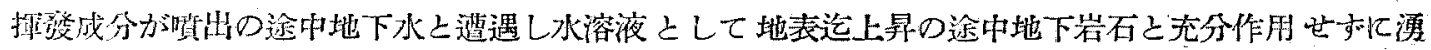

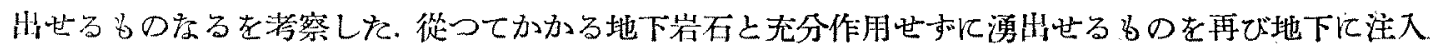

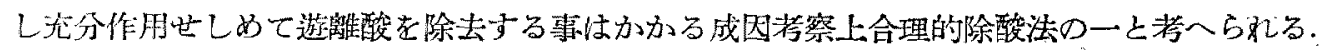

\section{7. 湯花に就きて}

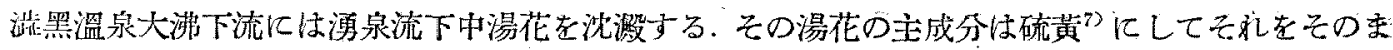

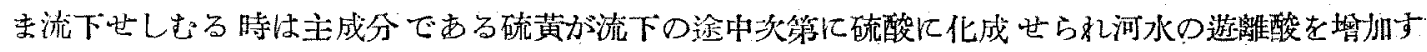

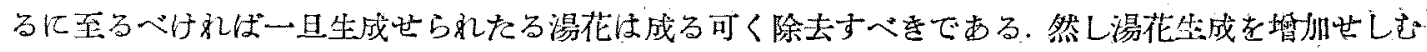

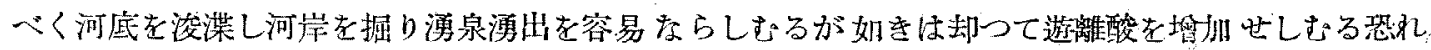
あるものはれば注意を要する。

\section{II. 玉川下流に於ける遊離酸除去法}

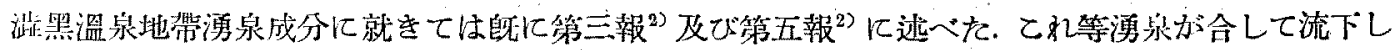
滥黑川に注定, 更飞五十曲にて玉川本流飞合流し小和瀨川, 大先澾川, 生保內川, 檜木內川等の支川を

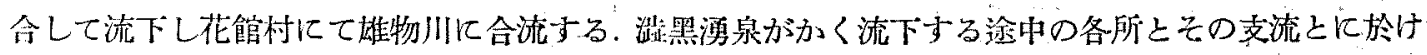

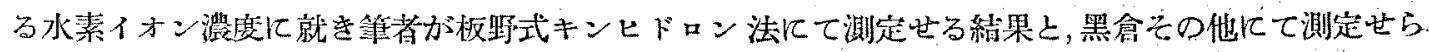
礼た王川流水量及び艺の兩者上り計算世る河水中の水素イオン總量とを第 4 表飞舉げる。此の絬果を 見るに王川在抱還附近迄流下するとその途中に於て拈離酸が著しく減少する事を示す..とれは新湯涌

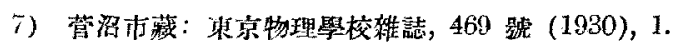




\begin{tabular}{|c|c|c|c|c|c|c|}
\hline 稫 號 & $\begin{array}{c}\text { 热 } \\
\text { 年 } \\
\text { (昭和) }\end{array}$ & 探水 & 所 & $p \mathbf{H}$ & 湤 $\underset{(1 / \mathrm{sec})}{\text { 水 }}$ 量 & $\begin{array}{c}\text { 河水 } \mathrm{H} \cdot \text { 總量 } \\
\mathrm{g} / \mathrm{sec}\end{array}$ \\
\hline 1 & 11.6 .8 & 涉㫮溫泉大沸北宸櫴泉 & & 1.01 & 139 & 13.6 \\
\hline 3 & 11.6 .9 & 湴黑川橋下(五十曲下) & & 2.35 & & \\
\hline 3 & $"$ & 玉川本旅 大燃濢 & & 6.33 & & \\
\hline 4 & $n$ & "锤部澤上手 & & 2.82 & & \\
\hline 5 & $"$ & "鹍の湯下手 & & 3.13 & & \\
\hline 6 & $"$ & "小澤上流釣橋下 & & 3.42 & & \\
\hline $\bar{T}$ & $"$ & " 小野草攞下手崖下 & & 3.56 & & \\
\hline 8 & 11.6 .10 & " 石神㭼下 & & 3.63 & & \\
\hline 9 & $"$ & " 抱還若松愊炆入口 & & 4.17 & 34400 & 2.3 \\
\hline 10 & '" & "㤬野鞋山橋附近 & & 5.54 & & \\
\hline 11 & $n$ & "王川橋下手 & & 6.06 & & \\
\hline 12 & $"$ & 雄物川大曲下 & & 6.32 & & \\
\hline 13 & $"$ & 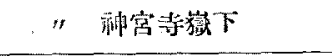 & & 6.26 & & \\
\hline 14 & 12.4 .27 & 互川廣久内上堰取入口 & & 4.78 & 160500 & 2.7 \\
\hline 15 & 12.7 .8 & 龇黑溫泉湯化肚水門河水 & & 1.13 & 139 & 10.3 \\
\hline 16 & $"$ & 龇熙川橋下(五十曲下) & & 2.12 & & \\
\hline 17 & $"$ & 正川新湯浙近河水 & & 2.61 & & \\
\hline 18 & " & 新湯涌泉 & & 8.00 & & \\
\hline 19 & 12.7 .9 & 明瀑湖 & & $6.5 \overline{5}$ & & \\
\hline 20 & $"$ & 大先涬川 & & 6.67 & & \\
\hline 21 & $"$ & 小先湭川 & & 7.82 & & \\
\hline 22 & $" \prime$ & ひのきない川 & & 7.25 & & \\
\hline 23 & $"$ & 黑摆川 & & 7.22 & & \\
\hline 24 & $"$ & 玨川抱還若松堰取入口 & & 4.31 & 63900 & 3.1 \\
\hline
\end{tabular}

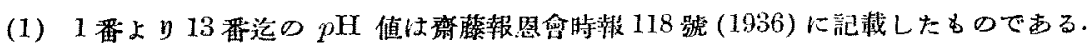

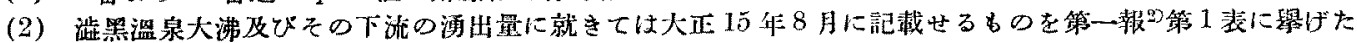

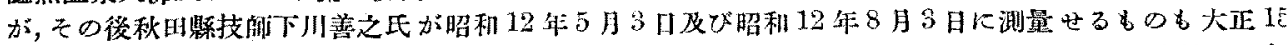

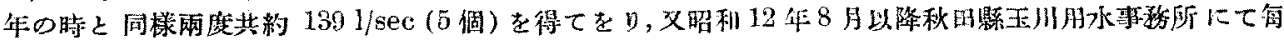

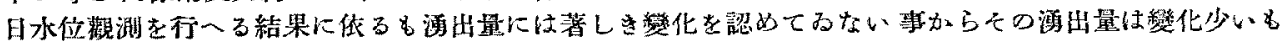

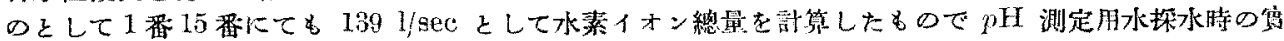
测做ではないが赛際の涌出量に近似のものと考一られる。

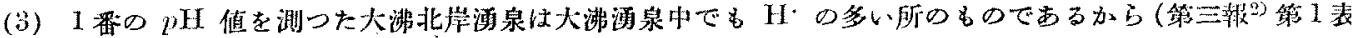
參照) $\mathrm{H} ・$ 總量 $13.6 \mathrm{~g} / \mathrm{sec}$ は大沸涌泉平均俌としては少しく過大になると思は机る。

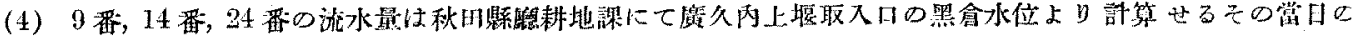
嘪湘值である.

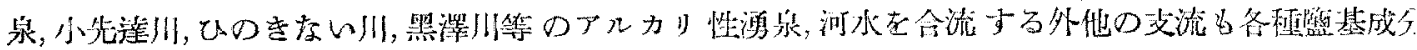

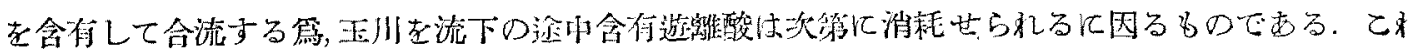

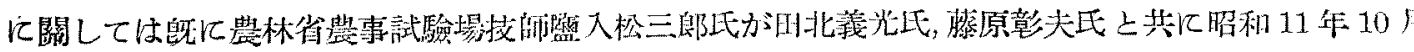

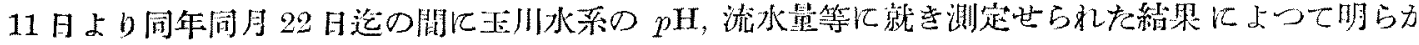

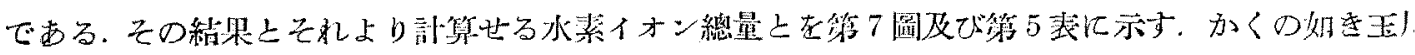

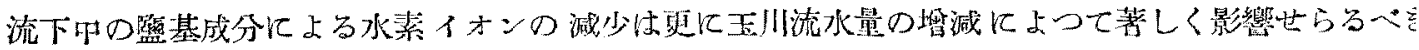




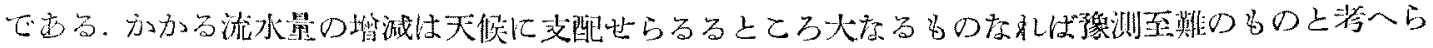

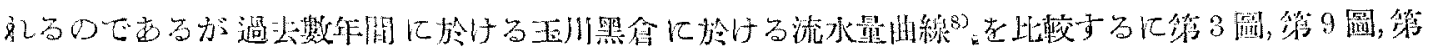

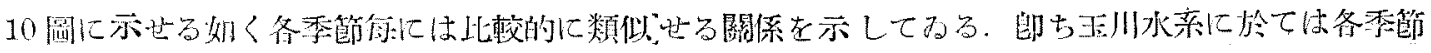

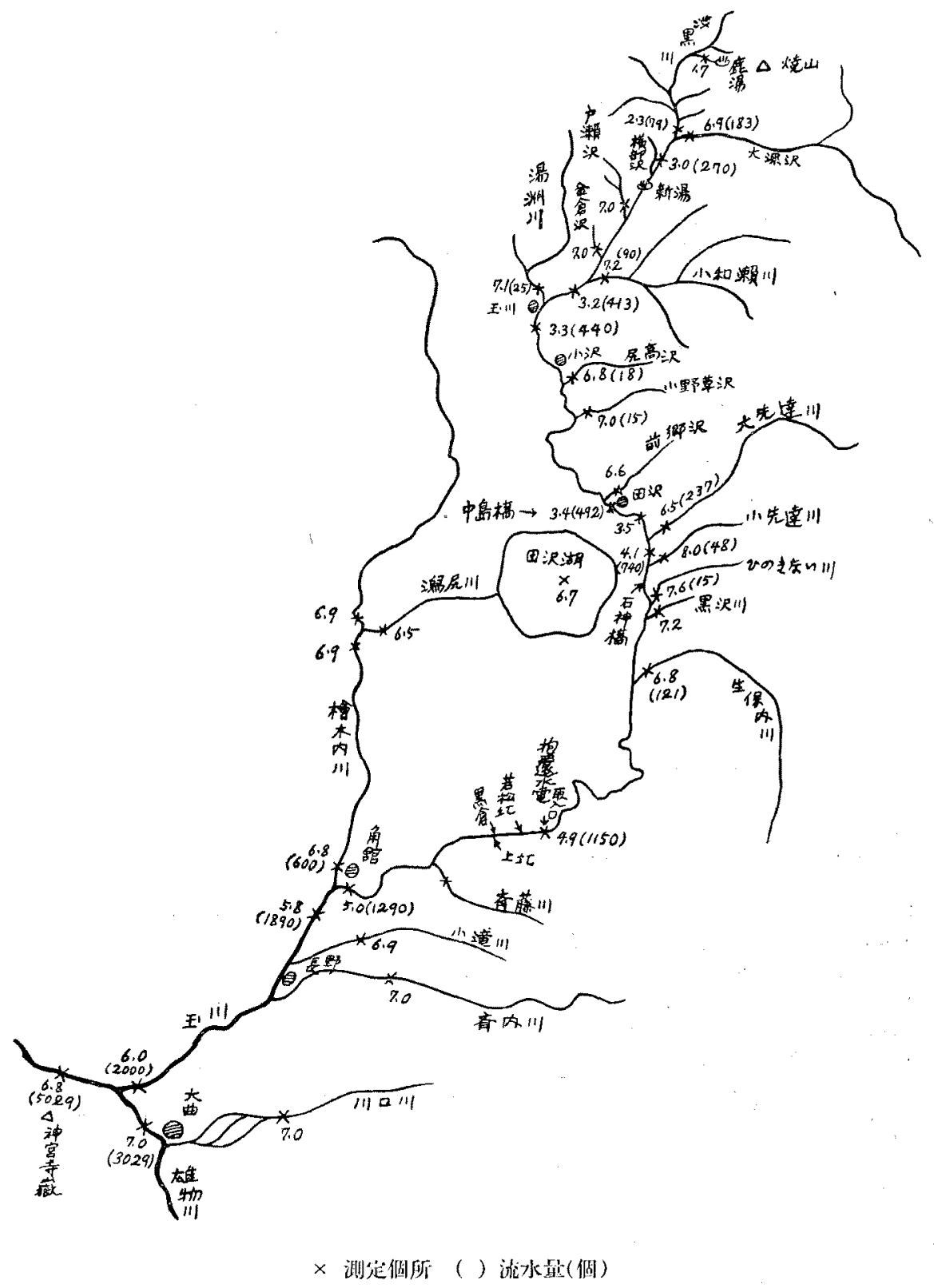

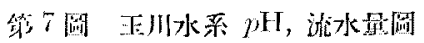

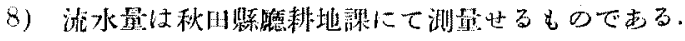




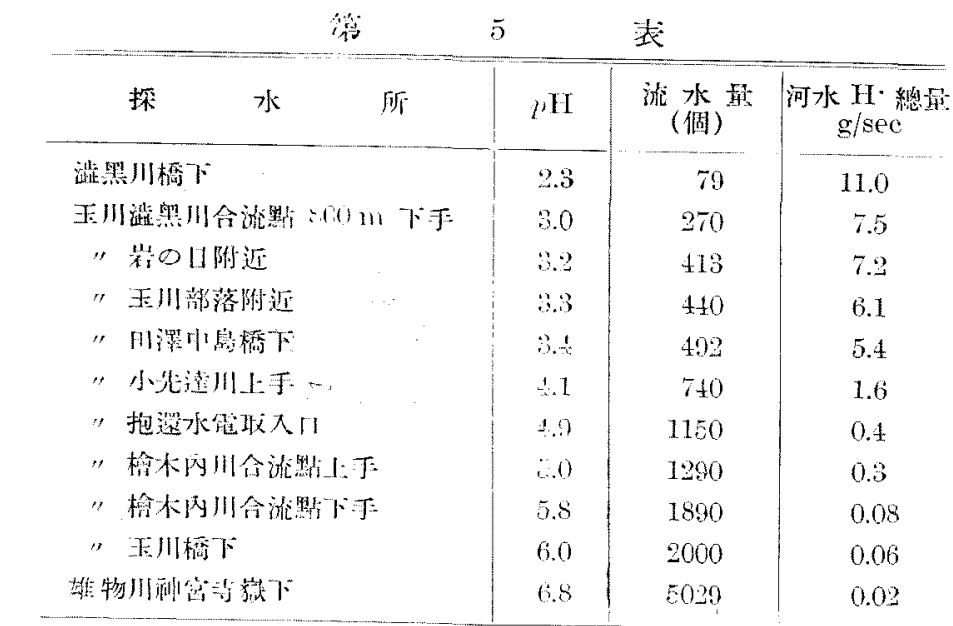

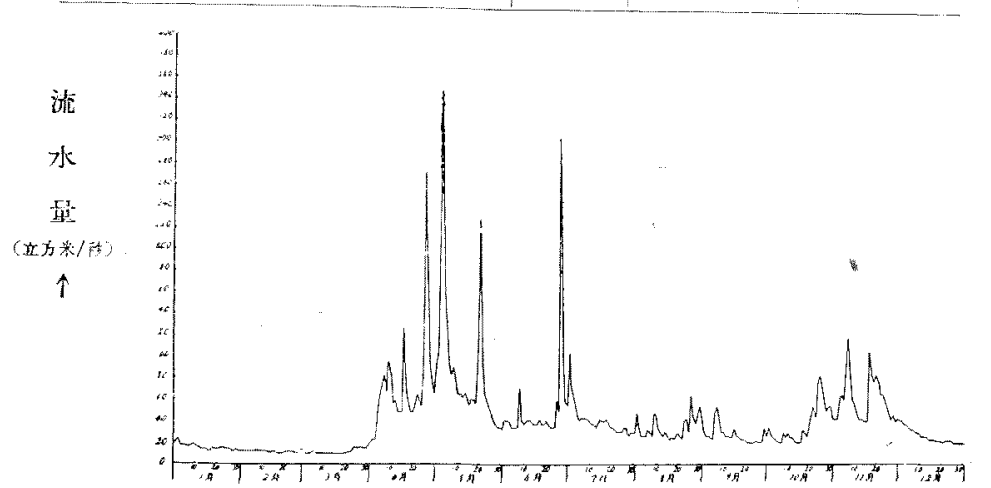

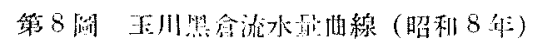

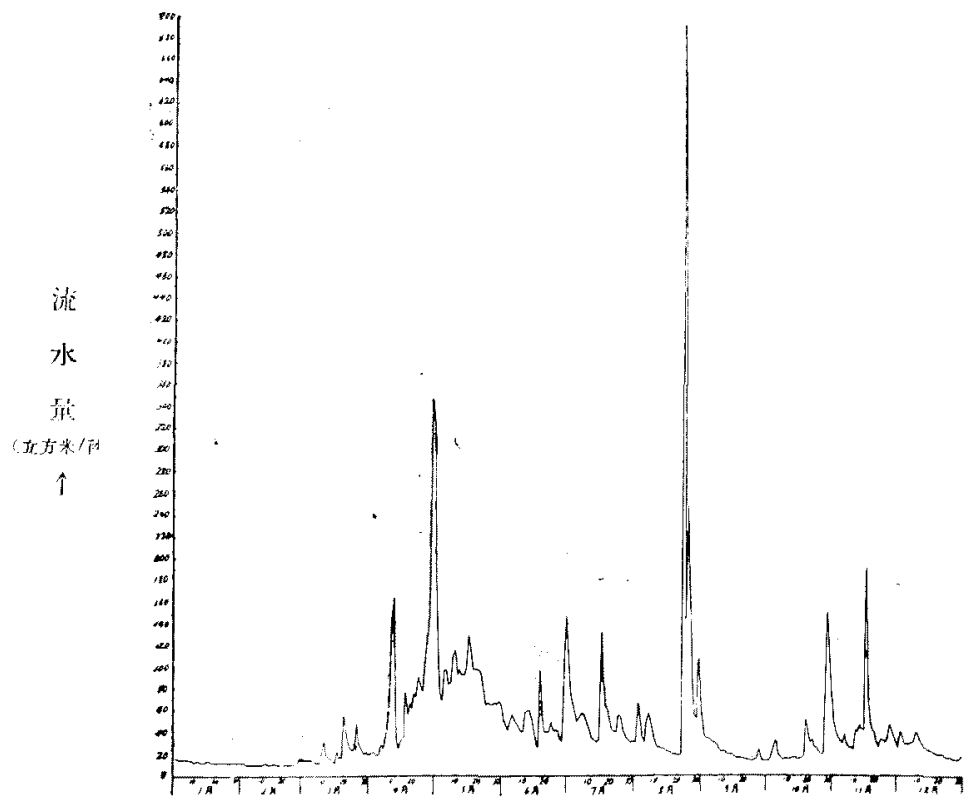

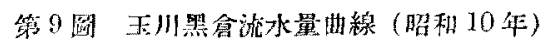

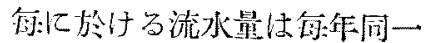

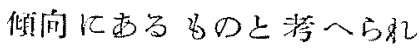
る. 從つて每年の玉川水系に

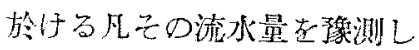

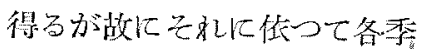
節每江影響在受ける水奖仿 ンの減少子凡气瑔测し得られ る为のと荐へられる。

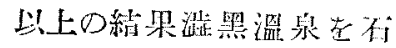
灰石, 生石灰の如龺中和剖在

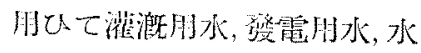

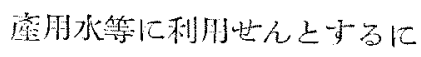
は上流化於て中和するよりる 成当可く下流に於て中租鸟れ ばそ礼丈印稩劑在減少せしめ ら礼る事在示すものでする。

此の下流汇於ける中和法在

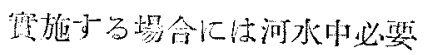
量丈在取入口上万分水㣪印和 ナできで且つ和䘞上しては 篗3 表惯驗 43,46 にて大理 石粉林心如等酸石灰にて子 迅速化作用与る事吸らかであ るから適常索る方法に上り石 灰石粉壮在使用与るのが好都

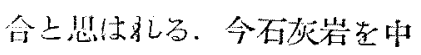
和剂化使用寸ると第 4 表の 1 の抱還取入口代於ける王川河 水企部の水素イオン總量を中 和与るに要する炭酸石灰は約 10进/日で酸化石灰にて約 5.6 继/日となる。

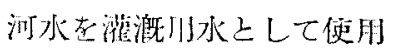
一る時には灌溉期閒中必要量 丈分水し中和与礼ば上いわ けでする. 今水脚け期間索 100 日とし, $p \mathrm{H}=4.17$ の河 水在分水し中和与る場合の 1 叮少澢りの所要炭酸石灰, 酸 化不灰量老計算して子多. 即 


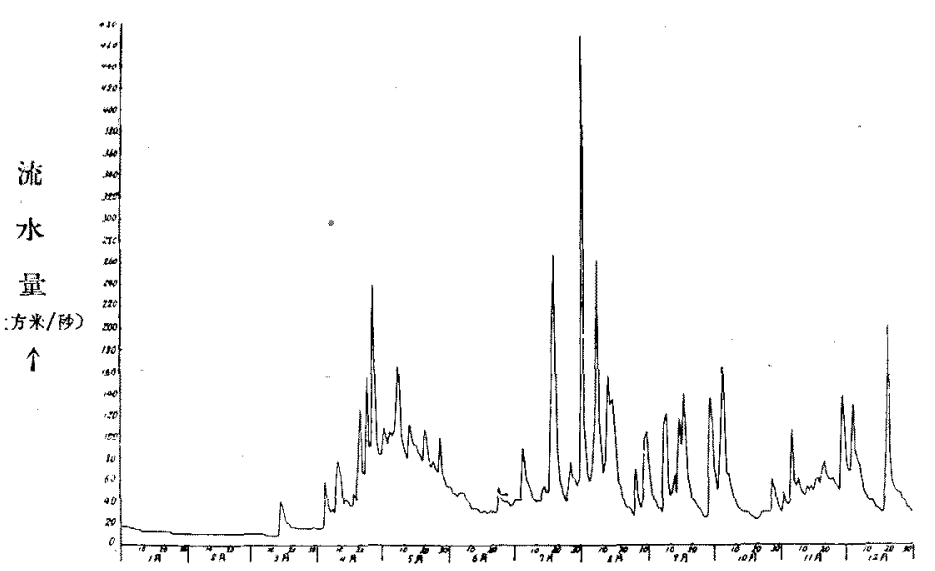

第 10 阐 王川黑合流水量曲線（昭和11 年)

\begin{tabular}{|c|c|c|c|c|c|}
\hline 番 號 & $\begin{array}{c}\text { 探 } \\
\text { 年 } \\
\text { (昭和) }\end{array}$ & 永 & $\begin{array}{c}\text { 地下注入前 } \\
\text { 河水 } \\
(p \mathrm{H})\end{array}$ & $\begin{array}{l}\text { 地下注入後 } \\
\text { 漏出水 } \\
(p H)\end{array}$ & $\begin{array}{l}\text { 啮黑川橋下 } \\
\text { 河永 } \\
(p \mathrm{H})\end{array}$ \\
\hline 1 & 13. 7. & 3 & 1.1 & 2.8 & \\
\hline 2 & $"$ & 7 & $"$ & - & 2.8 \\
\hline 3 & $"$ & 16 & $"$ & 2.9 & \\
\hline 4 & $"$ : & 24 & " & 2.9 & \\
\hline 5 & $"$ : & 26 & $"$ & 2.9 & \\
\hline 6 & $" 1$ & 30 & $"$ & 2.9 & \\
\hline 7 & 13.8 & 11 & $" \prime$ & 2.9 & \\
\hline 8 & $" \prime$ & 21 & " & - & 2.7 \\
\hline 9 & 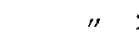 & 25 & $"$ & 2.8 & 2.8 \\
\hline 10 & $"$ & 28 & $"$ & 2.8 & 2.8 \\
\hline 11 & $" \prime$ & 29 & $"$ & 2.8 & \\
\hline 12 & 13.10 & 29 & $"$ & 2.7 & 2.8 \\
\hline 13 & 13.11. & 23 & $m$ & - & 3.1 \\
\hline
\end{tabular}

（1）13番は地下注入點を壁道出口より水路 120 間下の水路附 近に變更せる整日のものである。
ち古田住蒸發, 渗透等による娍

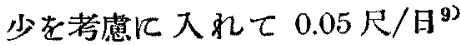
の水深の水量を整すると見られ 万加 51 町步虽”b約 150000 泣/月の所要水量上素る。すると 所要炭酸石灰は的 $500 \mathrm{I} / \mathrm{日}$ 疗口酸化石灰は約 280 瓦/日之 疗る.從つて 100 日閻では桨酸石 灰は約50 正, 酸化石灰的 28 互裂 与る事上なる。師ち傕搬賴等索 㸝へざる岑酸石灰のみの橿費は 僅少にて足万事が知ら引る。

發電所用水 ${ }^{10}$ D加定完中

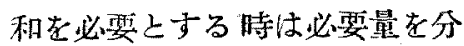
水し竾酸石灰にて中和するのが 得策亡洘入 5 礼る。

\section{III. 演泉の地下注入法 實施狀況}

王川清水除害事業怯秋田縣聽 にて買施しつつある事は饭に抯 著玉川毒水除寞の沿革と現牒 に述へた事であるが昭和 12 年

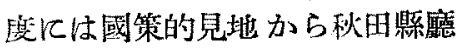
に於て夕積栖的儿除害工事老施

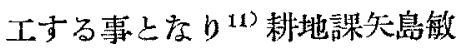
斑氏，後藤與治氏，下川羓之氏， 仍慗賢藏氏等の努力により昭和 13 年 6 月 22 日上降湧泉の長期 地下注入汃賽施世らるるに至つ

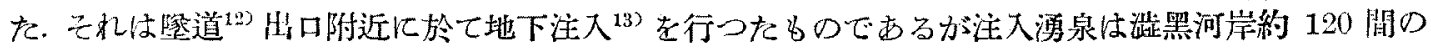

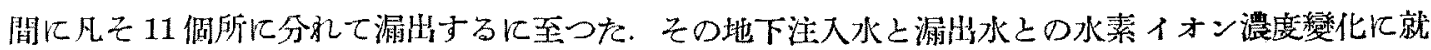

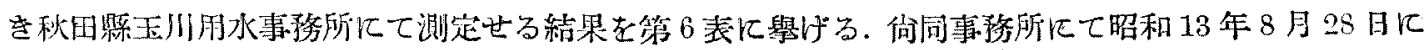

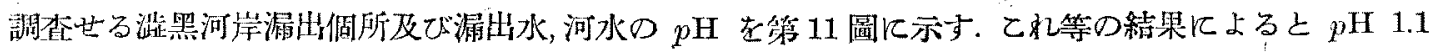

9) 開愁田ならば 0.1 尺/日の水深を要すると見られるから古田の 2 倍に常る.

10) 五川水系にてはこれ迄

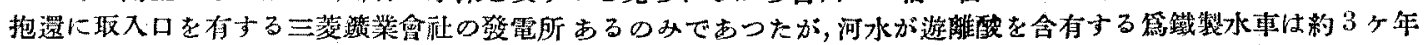

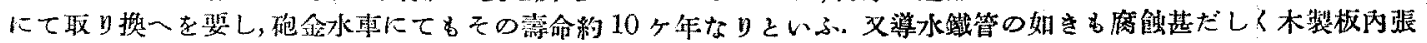

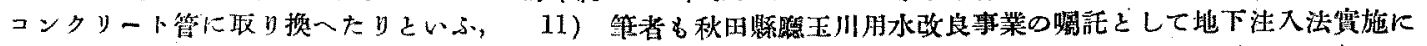

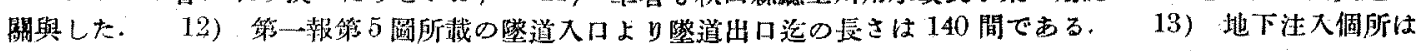

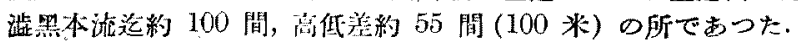




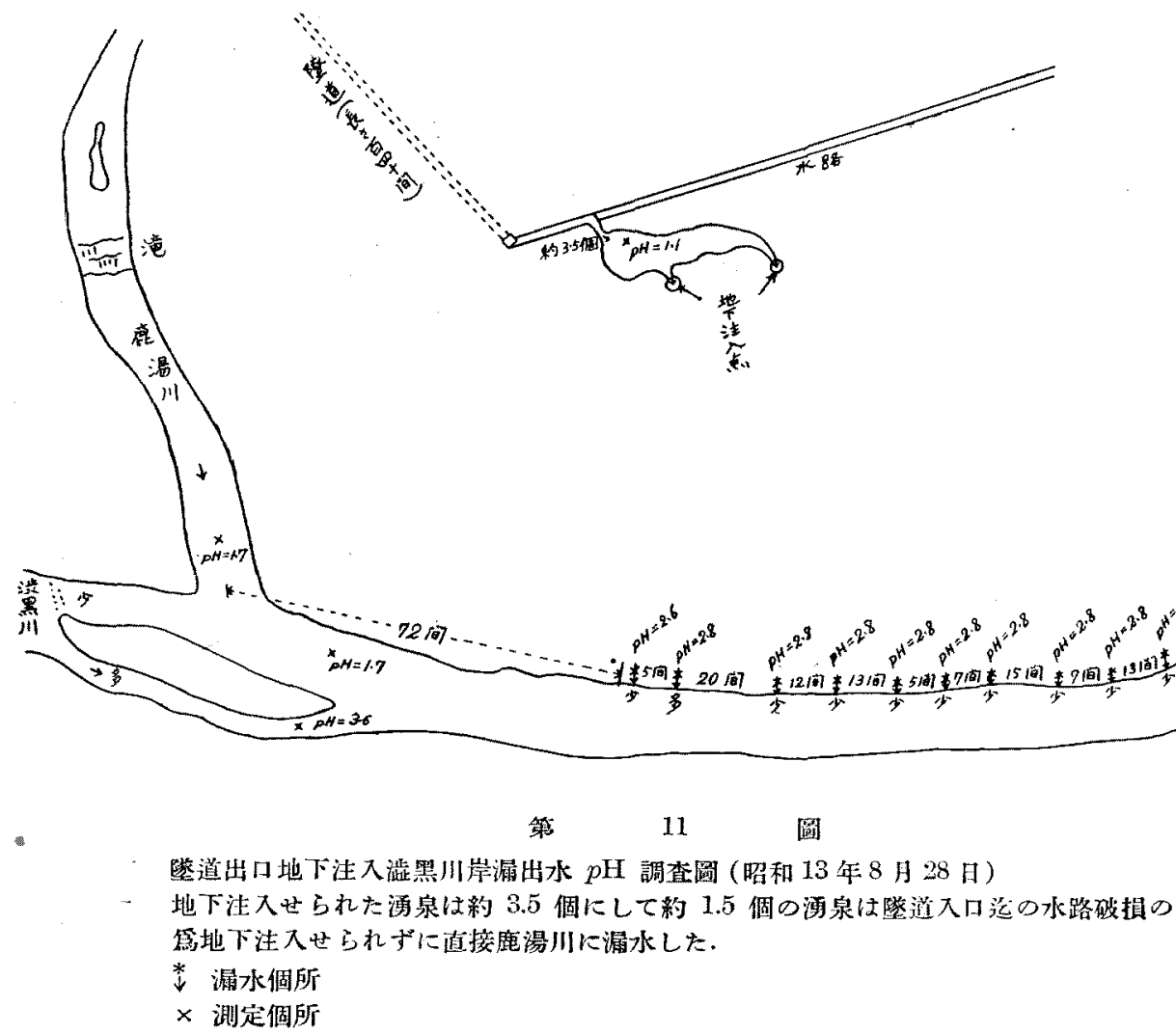

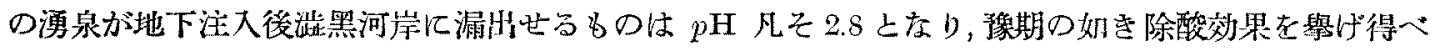

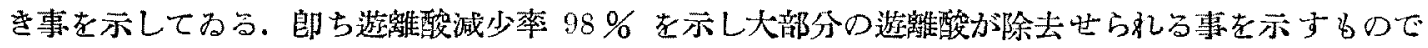

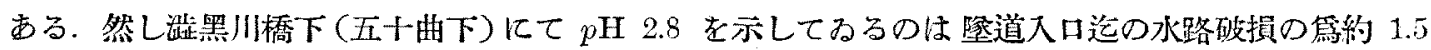

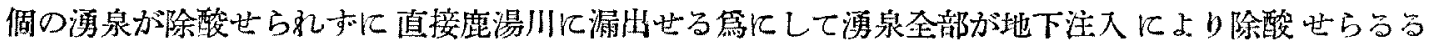

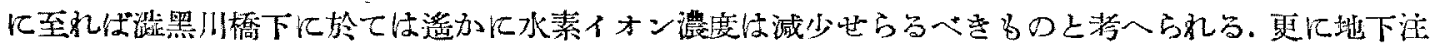

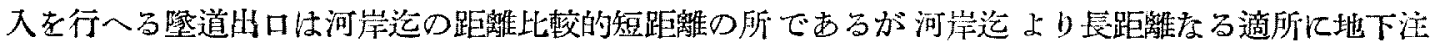

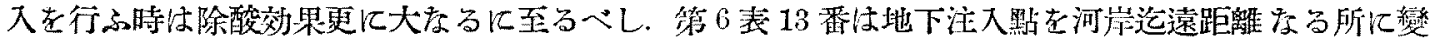

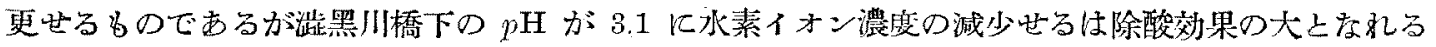
事を立證するるのである。

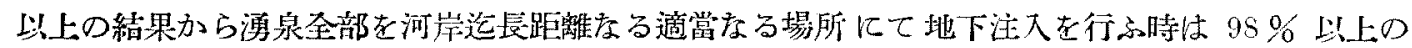
遊離酸除去を滓成し得へき事を示するので從つて下流に於てもてれに應じて水素イオン澧度の著し

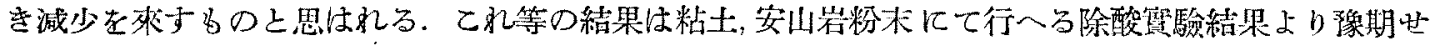
るが如き除酸效果を舉げ得べき事を立登世るるので,かかる地下注入法の些だ有效なるこ上を示せら

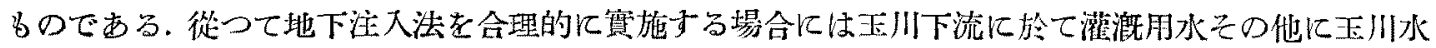

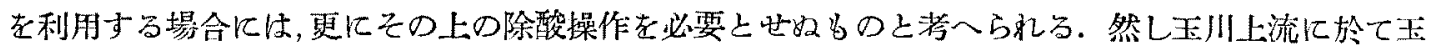

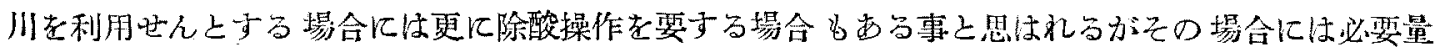

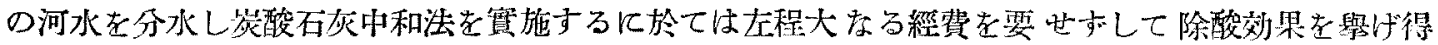
べをるの上溚へられる。 


\section{IV. 他の遊離酸含有河川に地下注入法を適用する場合}

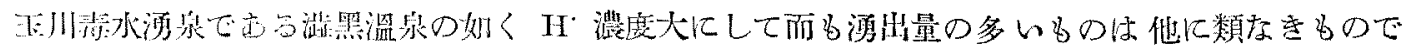

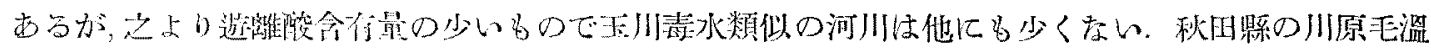

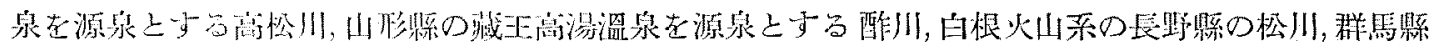

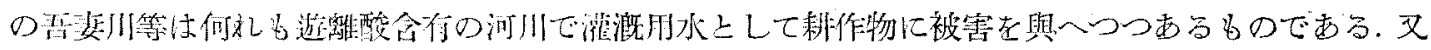

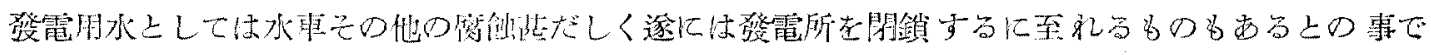

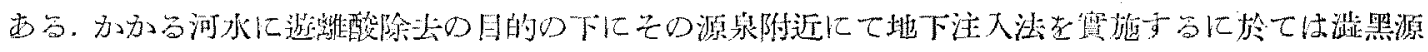

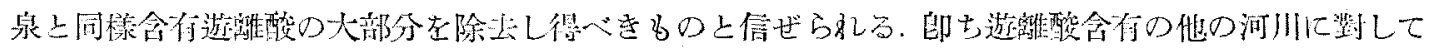

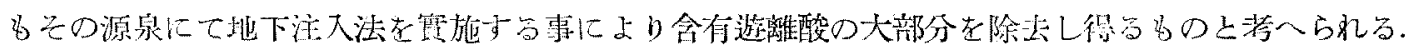

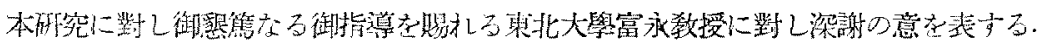

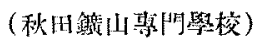

